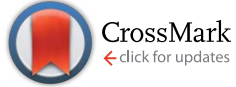

Cite this: J. Mater. Chem. A, 2015, 3, 3011

Received 7th November 2014 Accepted 17th December 2014 DOI: $10.1039 / c 4 t a 06029 f$ www.rsc.org/MaterialsA

\section{Nanoparticle scaffolds for syngas-fed solid oxide fuel cells}

\author{
Paul Boldrin, ${ }^{\text {a }}$ Enrique Ruiz-Trejo, ${ }^{a}$ Jingwen $\mathrm{Yu}^{\mathrm{b}}{ }^{\mathrm{R}}$ Robert I. Gruar, ${ }^{\mathrm{c}}$ \\ Christopher J. Tighe, ${ }^{c}$ Kee-Chul Chang, ${ }^{d}$ Jan Ilavsky, ${ }^{e}$ Jawwad A. Darr ${ }^{c}$ \\ and Nigel Brandon ${ }^{a}$
}

Incorporation of nanoparticles into devices such as solid oxide fuel cells (SOFCs) may provide benefits such as higher surface areas or finer control over microstructure. However, their use with traditional fabrication techniques such as screen-printing is problematic. Here, we show that mixing larger commercial particles with nanoparticles allows traditional ink formulation and screen-printing to be used while still providing benefits of nanoparticles such as increased porosity and lower sintering temperatures. SOFC anodes were produced by impregnating ceria-gadolinia (CGO) scaffolds with nickel nitrate solution. The scaffolds were produced from inks containing a mixture of hydrothermally-synthesised nanoparticle CGO, commercial CGO and polymeric pore formers. The scaffolds were heat-treated at either 1000 or $1300{ }^{\circ} \mathrm{C}$, and were mechanically stable. In situ ultra-small X-ray scattering (USAXS) shows that the nanoparticles begin sintering around 900-1000 ${ }^{\circ} \mathrm{C}$. Analysis by USAXS and scanning electron microscopy (SEM) revealed that the low temperature heat-treated scaffolds possessed higher porosity. Impregnated scaffolds were used to produce symmetrical cells, with the lower temperature heat-treated scaffolds showing improved gas diffusion, but poorer charge transfer. Using these scaffolds, lower temperature heat-treated cells of $\mathrm{Ni}-\mathrm{CGO} / 200 \mu \mathrm{m}$ YSZ/CGO-LSCF performed better at $700{ }^{\circ} \mathrm{C}$ (and below) in hydrogen, and performed better at all temperatures using syngas, with power densities of up to $0.15 \mathrm{~W} \mathrm{~cm}^{-2}$ at $800^{\circ} \mathrm{C}$. This approach has the potential to allow the use of a wider range of materials and finer control over microstructure.

\section{Introduction}

Ceramic materials are of increasing interest beyond structural uses in areas such as solid oxide fuel cells,,$^{1,2}$ gas separation ${ }^{3,4}$ and catalytic reaction membranes, ${ }^{5,6}$ biomaterials $^{7}$ and optical devices. ${ }^{8}$ Incorporation of nanomaterials into these devices offers benefits such as an increase of surface area, lower temperature for onset of sintering, finer control over structure or access to new functionality. Up until now, the use of inorganic nanomaterials has been hampered by the difficulties of fabricating devices using traditional processing techniques such as screen printing or tapecasting. ${ }^{9}$ Large scale ceramic processing techniques typically involve formulating an ink by suspending inorganic particles in a solvent medium, using organic dispersants and binders. ${ }^{10}$ This ink is then used to form a free standing monolith (e.g. tape casting) or a thin layer on a

\footnotetext{
${ }^{a}$ Department of Earth Science \& Engineering, Imperial College London, London SW7 2AZ,UK. E-mail: p.boldrin@imperial.ac.uk

${ }^{b}$ Department of Chemical Engineering, Imperial College London, London SW7 2AZ, UK 'Department of Chemistry, University College London, London WC1H OAJ, UK ${ }^{d}$ Materials Science Division, Argonne National Laboratory, Argonne, IL 60439, USA ${ }^{e} X$-ray Science Division, Argonne National Laboratory, Argonne, IL 60439, USA
}

support (e.g. screen printing). Increasing the loading of particles usually improves properties in the final product such as increased density, better particle interconnectedness, and potentially increased adhesion to the substrate and uniformity. ${ }^{11-13}$ The increase in particle loading can increase ink viscosity and at some point the suspension becomes too viscous to readily process. One difficulty with using nanomaterials has been to be able to incorporate a high enough solid loading to maintain the required high density and uniformity but with a low enough viscosity in the ink to allow processing.

Solid oxide fuel cell anodes require carefully engineered structures with specific material properties. ${ }^{14}$ Typically the anodes are two phase materials, e.g. an oxide-conducting ceramic and an electron-conducting metal, and these are required to percolate throughout the structure. Electrochemical reactions take place at the triple phase boundary between metal, ceramic and gas, therefore a porous three dimensional structure is necessary. Also, good adhesion to both the electrolyte (an oxide-conducting ceramic) and the current collector (a metal) are required to minimise ohmic losses. Normally an ink of nickel oxide and doped zirconia or ceria is screen printed onto the electrolyte and sintered at $>1300{ }^{\circ} \mathrm{C}$, which is the temperature needed to produce physically-stable films. 
Mixing the metal and oxide phases before formation of the three dimensional anode structures limits the independence with which chemistry and microstructure can be investigated and the high calcination temperatures place limitations on the materials used and the size of the structural features that can be obtained. One fabrication method with the capability of separating microstructure fabrication from chemistry is the printing of inks containing only the ceramic content plus sacrificial pore formers which are removed on heat-treatment. ${ }^{15,16}$ This method forms a high porosity scaffold to which the metal phase can then be introduced by impregnation or electroless deposition. Hitherto, this method has only used conventional $(>1 \mu \mathrm{m})$ sized particles for the scaffold. The use of nanomaterials may be able to produce finer microstructures, enhance the porosity further and allow use of new materials. Herein, we report on the fabrication of doped ceria scaffolds using a mixture of nano and larger commercial particles, with pore formers. We demonstrate that the incorporation of the nanoparticles with their lower onset of sintering temperature, results in physically-stable electrodes after sintering at only $1000{ }^{\circ} \mathrm{C}$, giving electrodes with significantly higher porosity and producing cells with superior low temperature performance compared to cells produced using a standard heat-treatment temperature of $1300{ }^{\circ} \mathrm{C}$ in hydrogen and at all temperatures in syngas fuel.

\section{Experimental}

Fig. 1 summarises schematically the formulation and fabrication procedures used in the paper. Inks were formulated from a mixture of commercial gadolinia-doped ceria $\left(\mathrm{Ce}_{0.9} \mathrm{Gd}_{0.1} \mathrm{O}_{1.97}\right.$, CGO, particle size $=0.5 \mu \mathrm{m}$ ) from Praxair, nanoparticle CGO $\left(\mathrm{Ce}_{0.9} \mathrm{Gd}_{0.1} \mathrm{O}_{1.97}\right.$, particle size $=5 \mathrm{~nm}$ from $\left.\mathrm{TEM}\right)$ produced by continuous hydrothermal flow synthesis (CHFS), polymer microbeads (6 $\mu \mathrm{m}$, Microbeads AS, Spheromers CA6), terpineol as a solvent, Hypermer KD15 as a dispersant and an ethylcellulose binder (Hercules EC N-7). The CGO nanopowders were produced by continuous hydrothermal flow synthesis using a pilot plant at University College London as described elsewhere. ${ }^{17}$ CHFS is emerging and scalable method of preparing nanoparticles and has previously been used to make samaria-

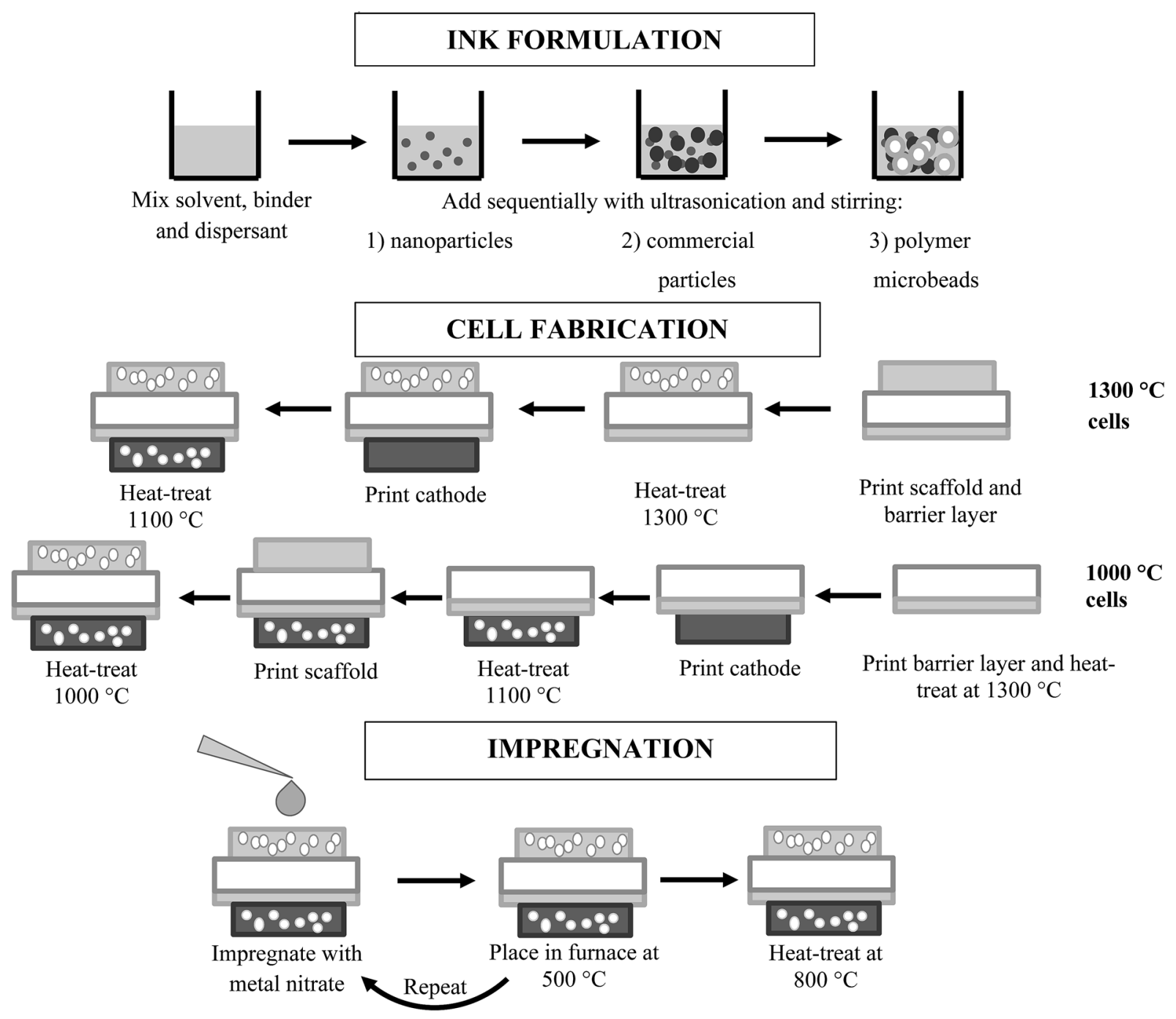

Fig. 1 Schematic of the ink formulation, fuel cell fabrication and impregnation procedures. 
doped ceria, ${ }^{3}$ ceria-zirconia solid solutions, ${ }^{18,19}$ an entire phase diagram of 66 ceria-zirconia-yttria samples ${ }^{20}$ and a range of other metal oxides ${ }^{21,22}$ and phosphates ${ }^{23}$ with typically sub 50 $\mathrm{nm}$ diameter. In CHFS, an aqueous mixture of cerium ammonium nitrate and gadolinium nitrate solution was continuously mixed with a stream of superheated water at $450{ }^{\circ} \mathrm{C}$ and 22.1 MPa in a patented confined jet mixer. ${ }^{24}$ Particles were then cooled (via a pipe cooler) and then collected as an aqueous slurry at the exit of the back-pressure regulator. The particles were recovered by centrifugation and washing (three times) in an equal volume of water until the final solid sludge was obtained. The nanopowder was recovered by freeze drying.

For preparation of scaffolds, the solvent $(0.653 \mathrm{~g})$, dispersant $(0.265 \mathrm{~g})$ and binder $(0.040 \mathrm{~g})$ were mixed together until the binder had fully dissolved. Next, with stirring in an ultrasonic bath, each solid component was added sequentially in two or three aliquots, starting with the dried CGO nanoparticles ( 0.751 $\mathrm{g})$, followed by the commercial CGO $(1.047 \mathrm{~g})$, and finally the polymer microbeads $(0.153 \mathrm{~g})$. The ultrasonication and stirring is effective in suspending the nanoparticles. This gave an ink with $c a .26$ vol\% solids content, which was an acceptable level for a screen printing ink. ${ }^{11}$ In formulating the ink, two conditions were sought: high total solid content and high nanoparticle content. The order of addition was important to ensure that the nanoparticles were fully incorporated and homogenised, and the large differences in particle size between the different components helped to maintain an appropriate viscosity at high solid loadings.

The inks were screen printed onto $200 \mu \mathrm{m}$ thick yttria-stabilised zirconia (YSZ) electrolytes. In the case of fuel cells, the procedure differed slightly between cells with different sintering temperatures for the anode, as shown schematically in Fig. 1. In the cells with scaffolds sintered at $1300{ }^{\circ} \mathrm{C}$, one side was printed with the scaffold ink, while the other was printed with a thin layer of a CGO ink (this is to prevent reactions between the cathode material and the YSZ electrolyte). The printed pellets were then heat-treated at $1300{ }^{\circ} \mathrm{C}$ for one hour, with a $1{ }^{\circ} \mathrm{C} \min ^{-1}$ ramp rate during heating and cooling. The LSCF-CGO cathode (ink purchased from Fuel Cell Materials, Columbus, OH, USA) was then screen-printed, and the cell heattreated at $1100{ }^{\circ} \mathrm{C}$ for three hours with a $5{ }^{\circ} \mathrm{C} \min ^{-1}$ ramp rate during heating and cooling. The process for the cells with scaffolds heat-treated at $1000{ }^{\circ} \mathrm{C}$ was identical except the order of printing and sintering was a protective CGO layer first, followed by cathode and finally by the CGO scaffold. Cells with one, two or three layers of CGO scaffold were produced. The scaffold was dried in an oven at $\sim 80{ }^{\circ} \mathrm{C}$ in between each printing cycle.

Next, the CGO scaffolds were impregnated with a nickel salt, again shown schematically in Fig. 1 . The impregnation solution was prepared from $0.125 \mathrm{~g}$ of nickel nitrate hexahydrate in 200 $\mu \mathrm{L}$ of absolute ethanol. The solution was dropped onto the scaffold using a 1-20 $\mu \mathrm{L}$ pipette, with the volumes used determined empirically by visually observing whether the drop spread beyond the edge of the scaffold. If it did, then the volume of the following impregnation was reduced. The first volume used was determined by dropping pure ethanol onto the scaffold. In between each impregnation, the pellets were placed into a furnace directly at $500{ }^{\circ} \mathrm{C}$ for $5 \mathrm{~min}$. This cycle was then repeated ten times. After the final impregnation, the pellets were placed into this furnace, and the temperature was increased to $800{ }^{\circ} \mathrm{C}$ at $5{ }^{\circ} \mathrm{C} \mathrm{min}^{-1}$ and held for eight hours before cooling at $5{ }^{\circ} \mathrm{C} \mathrm{min}^{-1}$. The NiO loading was determined by weighing.

Four symmetrical cells were produced: a single layer cell heat-treated at $1300{ }^{\circ} \mathrm{C}$; a single layer cell heat-treated at 1000 ${ }^{\circ} \mathrm{C}$; a double layer cell heat-treated at $1000{ }^{\circ} \mathrm{C}$ and a triple layer cell heat-treated at $1000{ }^{\circ} \mathrm{C}$. In addition, four button cells for fuel cell testing were produced from single and double layer CGO scaffolds heat-treated at $1000{ }^{\circ} \mathrm{C}$, and the same heattreated at $1300{ }^{\circ} \mathrm{C}$.

The scaffolds were studied by Ultra Small Angle X-ray Scattering (USAXS) to obtain information about the pore structure, while the in situ measurements allowed us to monitor the development of the microstructure with temperature. ${ }^{25}$ For the USAXS measurements, single layered samples were printed onto MgO substrates (used instead of YSZ as it is less absorbing of X-rays) for analysis by USAXS, and heat-treated at either 1000 or $1300{ }^{\circ} \mathrm{C}$. These samples were compared to a scaffold made from a "control" ink in which the nanoparticle component was replaced by extra commercial CGO. One sample printed on $\mathrm{MgO}$ was heat-treated in situ. The USAXS data were taken at sector 15, Advanced Photon Source, Argonne National Laboratory. Briefly, small angle scattering intensities around the direct beam was measured using channel cut Si crystal monochrometers in a Bonse-Hart configuration. The X-ray energy was $16.8 \mathrm{keV}$ and the beam size was $1.5 \times 0.4 \mathrm{~mm}$. The sample was mounted in a LinkAm heater for the in situ USAXS measurements. The USAXS intensity is plotted as a function of the scattering vector $q=$ $4 \sin (\theta) / \lambda$ where $\lambda$ is the X-ray wavelength and $\theta$ is the scattering angle. The USAXS spectra can be viewed as the autocorrelation of the electron density fluctuations inside the sample, resulting from contrast between the pores and the powders. The USAXS is normally plotted in a log-log plot, and at low $q$ Guinier approximation is valid so the USAXS intensity shows an inflection proportional to $-\exp \left(q^{2} R_{\mathrm{g}}{ }^{2} / 3\right)$ where $R_{\mathrm{g}}$ is the radius of gyration. At higher $q$ values, the USAXS intensity follows a power law slope with an exponent of -3 , as expected from Porod's law from slit-smeared USAXS. Our USAXS could not resolve the Guinier inflection from the large pores made by polymer microbeads, so we used a combination of a powder law slope and a log-normal size distribution of spherical pores to model the USAXS intensity for non-linear least squares fitting.

The scaffolds and impregnated anodes were imaged by FEGSEM (LEO Gemini 1525).

Electrochemical measurements were carried out with an Autolab PGSTAT. Symmetrical cell tests were carried out under humidified hydrogen in nitrogen, while fuel cell tests were carried out under humidified hydrogen in nitrogen and humidified syngas in nitrogen $\left(15 \% \mathrm{H}_{2}, 25 \% \mathrm{CO}, 60 \% \mathrm{~N}_{2}\right)$. The exact syngas composition with a high content of nitrogen was chosen so that some of the nitrogen can be replaced with other components (e.g. $\mathrm{CO}_{2}$, larger quantities of steam, tars or $\left.\mathrm{H}_{2} \mathrm{~S}\right)$ in later studies. For the syngas tests the cells were put under load 
in $50 \% \mathrm{H}_{2}$ in $\mathrm{N}_{2}$ before switching to syngas and carrying out the measurements. This avoids the carbon deposition caused by direct exposure to syngas at OCV. In all cases the same procedure for reducing the anode was employed; the cells were heated under dry nitrogen to $765{ }^{\circ} \mathrm{C}$ at $5{ }^{\circ} \mathrm{C} \min ^{-1}$ before switching to humidified $10 \%$ hydrogen in nitrogen for one hour before cooling to the operating temperature. In all cases in this report, the humidification was carried out at $20{ }^{\circ} \mathrm{C}$, giving a humidity of $2.3 \%$, while the gas compositions given refer to the gas compositions prior to humidification. It is expected that the fuel utilisations in these experiments will be very low due to the high gas flow rates and small electrode area, therefore no effects of fuel starvation will be seen.

\section{Results and discussion}

Scaffolds heat-treated at both $1300{ }^{\circ} \mathrm{C}$ and the lower temperature of $1000{ }^{\circ} \mathrm{C}$, showed structural stability and good adhesion to the electrolyte. This could be seen visually and was tested by placing Sellotape on the scaffold. The scaffold remained attached to the electrolyte when the Sellotape was removed. The fact that the scaffold heat-treated at $1000{ }^{\circ} \mathrm{C}$ was both structurally sound and well-bonded to the electrolyte was an interesting result, as the commercial CGO particles do not begin to sinter at this temperature. This was tested using an identical ink with the nanoparticle component replaced with commercial CGO. After calcination at $1000{ }^{\circ} \mathrm{C}$ this scaffold could be removed by the drafts resulting from opening the furnace. This indicates that the CGO nanoparticles are acting as a low temperature sintering aid (and a glue) to bind the scaffold together and allow it to adhere to the electrolyte. Imaging of the scaffolds by SEM (Fig. 2), revealed that the structures of the scaffolds heat-treated at different temperatures were different. Both scaffolds showed large pores of $c a .6 \mu \mathrm{m}$, which corresponded to the space left from removal of polymer microbeads. Other than these, the scaffold heat-treated at $1300{ }^{\circ} \mathrm{C}$ shows a structure typical of ceria heat-treated at such a high temperature, with no obvious indication of the presence of nanoparticles. The scaffold heattreated at $1000{ }^{\circ} \mathrm{C}$ showed much less agglomeration of particles, and the increase in surface area was obvious from visual inspection. The scaffolds had a thickness of $c a .10 \mu \mathrm{m}$.

The in situ USAXS results (Fig. 3) show the development of the pore structure with increasing temperature. In the samples heat-treated at low temperature, there was a bimodal pore size distribution. The smaller pores began to disappear in the range 766 to $927{ }^{\circ} \mathrm{C}$, and completely vanished by $c a .1150{ }^{\circ} \mathrm{C}$. The larger pores began to increase in size and decrease in volume above $1100{ }^{\circ} \mathrm{C}$. These results indicate that the onset of sintering for the nanoparticles began below $927^{\circ} \mathrm{C}$. This low onset of sintering suggests that a heat-treatment temperature of $1000{ }^{\circ} \mathrm{C}$ would be high enough to sinter the nanoparticles and produce a structurally-stable scaffold which was well-adhered to the electrolyte. This temperature should be close to the lower bound of feasible heat-treatment temperatures and so provides a sensible starting point ahead of future optimisation.

The analysis of the ex situ samples (Fig. 4) heat-treated at $1000{ }^{\circ} \mathrm{C}$ showed a much finer feature size and higher porosity

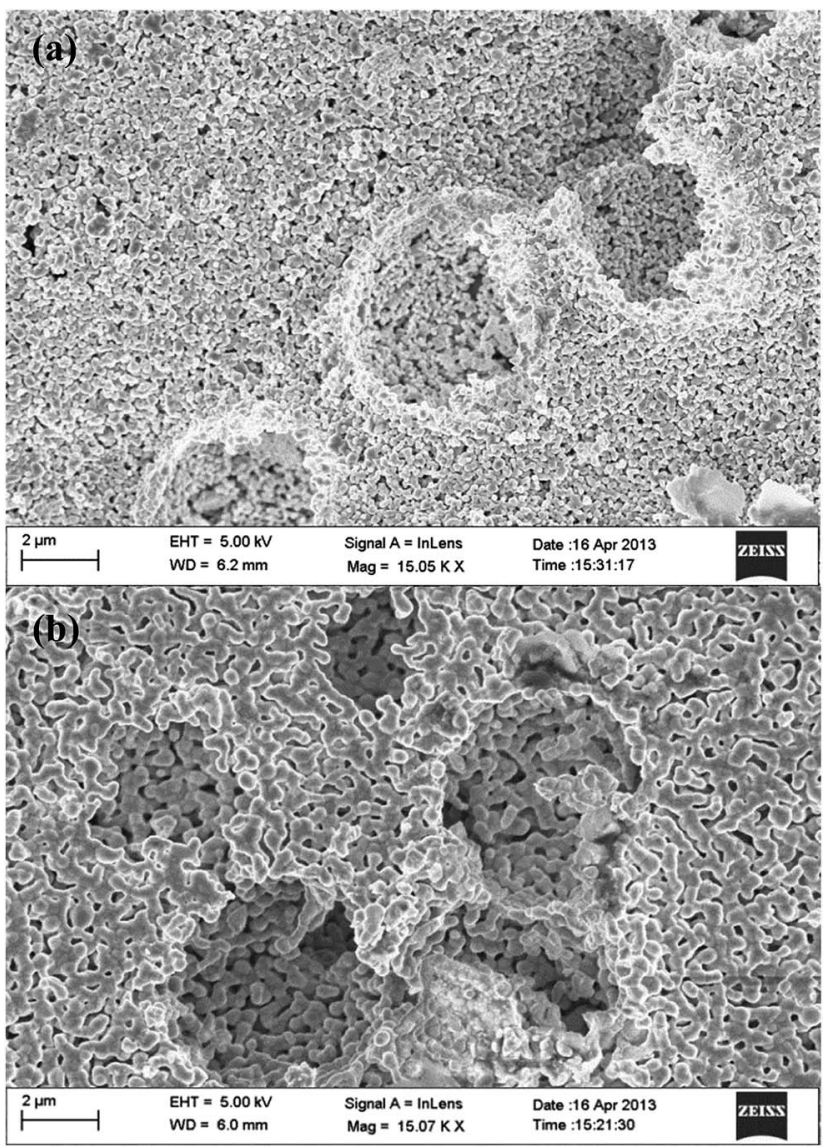

Fig. 2 Porous CGO scaffolds heat-treated at $1000^{\circ} \mathrm{C}\left(\right.$ a) and $1300^{\circ} \mathrm{C}$ (b) at $15 \mathrm{k}$ magnification.

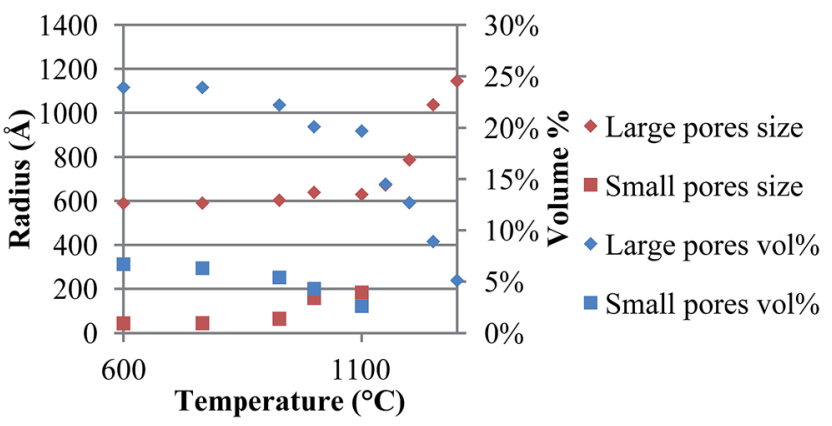

Fig. 3 Pore size and volume against temperature derived from in situ USAXS data.

compared to the scaffold heat-treated at $1300{ }^{\circ} \mathrm{C}$. Comparing the scaffold heat-treated at $1300{ }^{\circ} \mathrm{C}$ to a control sample produced without nanoparticles (heat-treated at $1300{ }^{\circ} \mathrm{C}$ ), suggested there were still some differences. This clearly suggested that the nanoparticles were having an effect despite the high calcination temperature. It is important to note that the USAXS analysis excluded the larger micron-scale porosity caused by the removal of the polymer microbeads. In the initial ink, these made up $35 \%$ of the solid volume, meaning that the porosity could have been as high as ca. 59\% in the scaffold heat-treated at $1000{ }^{\circ} \mathrm{C}$. 


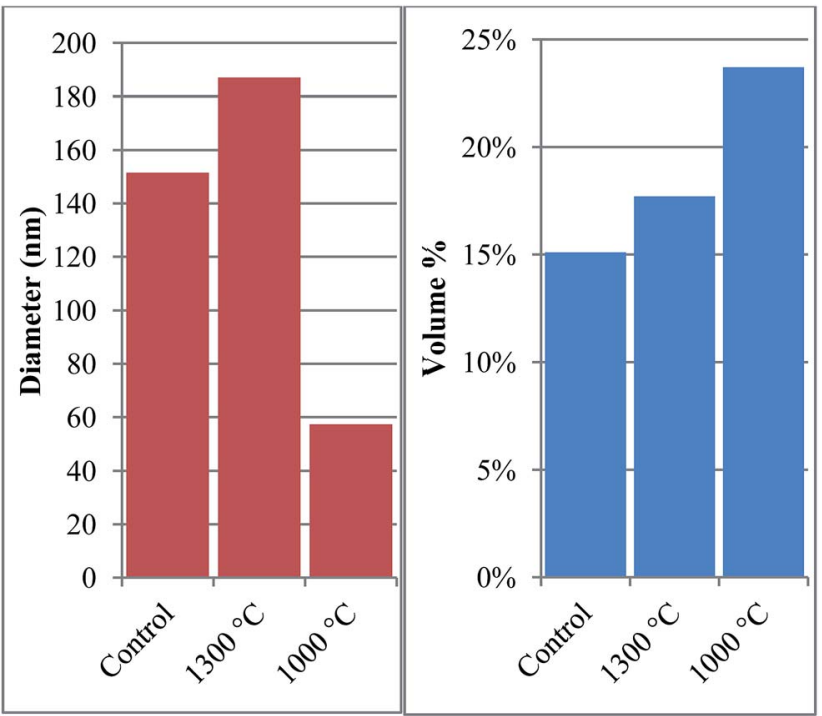

Fig. 4 Analysis of USAXS data showing pore diameters (left) and \% porosity (right) for scaffolds heat-treated at 1000 and $1300{ }^{\circ} \mathrm{C}$, and a control sample produced without nanoparticles and heat-treated at $1300^{\circ} \mathrm{C}$ (control).

The final step in the production of the cells was impregnation of nickel into the CGO scaffolds. This was achieved by impregnating them with nickel nitrate dissolved in ethanol, which on heat-treatment in air, became nickel oxide. SEM imaging (Fig. 5) of the scaffolds at different numbers of impregnations, showed that nickel oxide was initially deposited as isolated nanoparticles, which were then joined as the number of impregnations increases. ${ }^{26}$ From the SEM, a tentimes impregnated scaffold had most of the porosity filled in.

Table 1 shows the mass of nickel oxide deposited on the pellets. The theoretical mass of impregnated nickel oxide was very close to the measured mass. The volume of nickel solution added was determined empirically - it was decided whether to keep the same volume for the next impregnation or decrease the volume from observing whether the previous impregnation was fully absorbed or not. Because of this choice, the loading of nickel is not identical from cell to cell, with the loading of nickel decreasing with the number of layers of CGO that were put down. It is likely that this was because a greater number of layers decreased the ability of the nickel nitrate solution to absorb into the scaffold. From these values, combined with porosity values estimated from USAXS and the amount of microbeads present in the ink, it can be estimated that the volume of NiO impregnated may have been larger than the porosity of the scaffold in some cases by up to $20 \%$. In these cases, the excess $\mathrm{NiO}$ may have been deposited outside the scaffold.

Impregnated symmetrical cells were tested using impedance spectroscopy in order to assess the effects of scaffold calcination temperature and thickness of scaffold. Three cells heat-treated at $1000{ }^{\circ} \mathrm{C}$ were tested: single layer, double layer and triple layer. These were compared to a single layer cell produced using the same ink but calcined at $1300{ }^{\circ} \mathrm{C}$. This was used as a

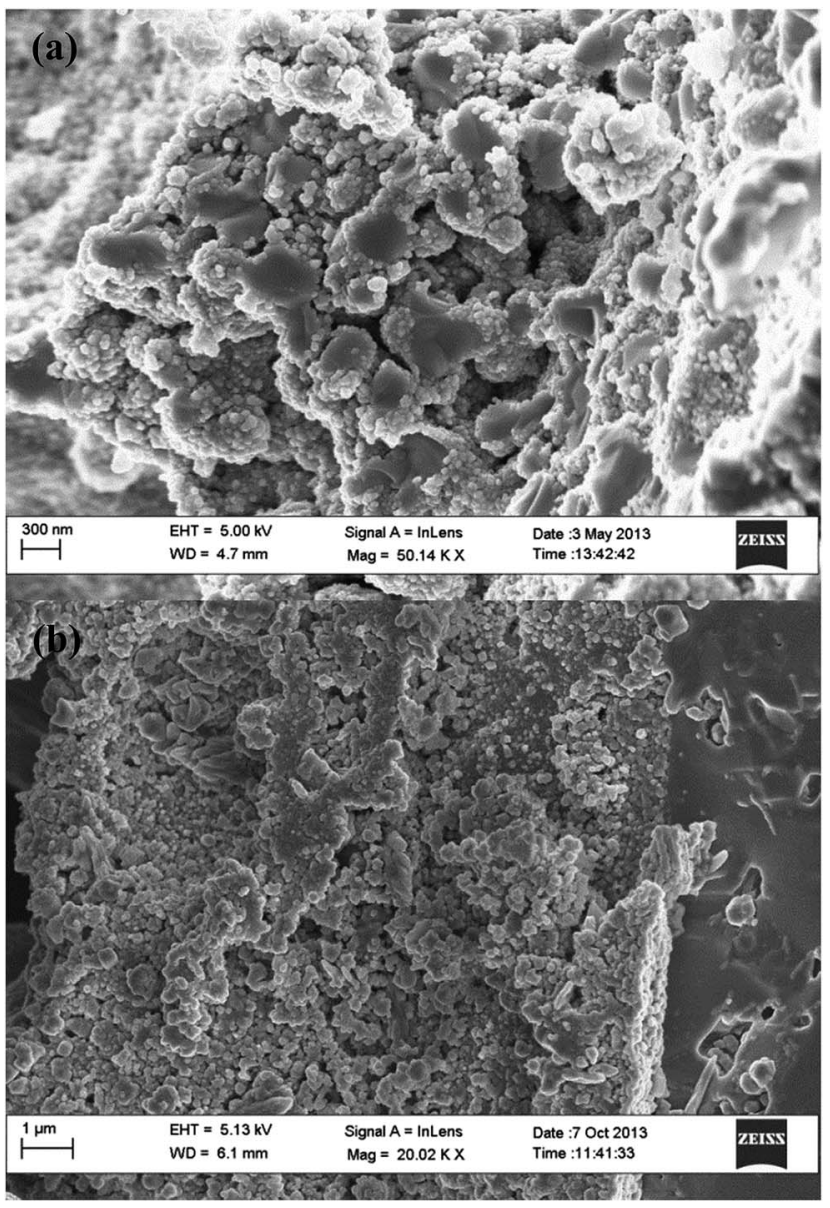

Fig. 5 SEM imaging of impregnated scaffolds (a) after five impregnations and (b) after ten impregnations.

comparison rather than a cell produced without using nanoparticles in order to avoid confounding factors such as changes in ink rheology which are known to affect cell performance. ${ }^{\mathbf{1 1 - 1 3}}$ Fig. 6 shows the impedance spectrum at $500{ }^{\circ} \mathrm{C}$ for the single layer cells as an example. All four cells show the two semi-circles typical of Ni-CGO anodes, with the high frequency response normally assigned to charge transfer processes, while the low frequency response is normally assigned to diffusion processes. Modelling these cells as equivalent circuits (inset of Fig. 6) shows that in this case, the assignments are consistent with this, as the high frequency response decreases in size exponentially with increasing temperature as expected from a thermally-activated charge transfer process, while the lower frequency response decreases in size with increasing hydrogen concentration, as expected from a diffusion-based process. For the low frequency response, the changes with hydrogen concentration are much less pronounced for the cells heattreated at $1000{ }^{\circ} \mathrm{C}$.

By examining the higher frequency response the authors have assigned as related to charge transfer, some differences between the anodes could be observed. Arrhenius plots of $\log _{10}$ of the resistance against inverse of the temperature are shown in Fig. 7. For the cells with scaffolds heat-treated at $1000^{\circ} \mathrm{C}$, the activation energy decreased as the number of layers increased, 
Table 1 Masses of CGO and $\mathrm{NiO}$ in pellets used in symmetrical and button cell tests

\begin{tabular}{|c|c|c|c|c|c|c|}
\hline \multirow{2}{*}{$\begin{array}{l}\text { Calcination } \\
\text { temp }\left({ }^{\circ} \mathrm{C}\right)\end{array}$} & \multirow[b]{2}{*}{ No. of layers } & \multirow[b]{2}{*}{ Symmetrical (S) or button (B) } & \multirow[b]{2}{*}{ Mass of CGO $(\mathrm{g})$} & \multicolumn{2}{|l|}{ Mass of $\mathrm{NiO}$} & \multirow[b]{2}{*}{ wt\% NiO } \\
\hline & & & & Theoretical (g) & Measured (g) & \\
\hline 1000 & 1 & $\mathrm{~S}$ & 0.0033 & 0.0077 & 0.0086 & 72.3 \\
\hline 1000 & 2 & $\mathrm{~S}$ & 0.0060 & 0.0092 & 0.0103 & 63.2 \\
\hline 1000 & 3 & $\mathrm{~S}$ & 0.0092 & 0.0104 & 0.0116 & 55.8 \\
\hline 1000 & 1 & $\mathrm{~B}$ & 0.0016 & 0.0039 & 0.0038 & 70.4 \\
\hline 1000 & 2 & $\mathrm{~B}$ & 0.0033 & 0.0046 & 0.0047 & 58.8 \\
\hline 1300 & 1 & $\mathrm{~S}$ & 0.0032 & 0.0082 & 0.0079 & 71.2 \\
\hline 1300 & 1 & $\mathrm{~B}$ & 0.0016 & 0.0041 & 0.0038 & 70.4 \\
\hline 1300 & 2 & B & 0.0032 & 0.0050 & 0.0058 & 64.4 \\
\hline
\end{tabular}

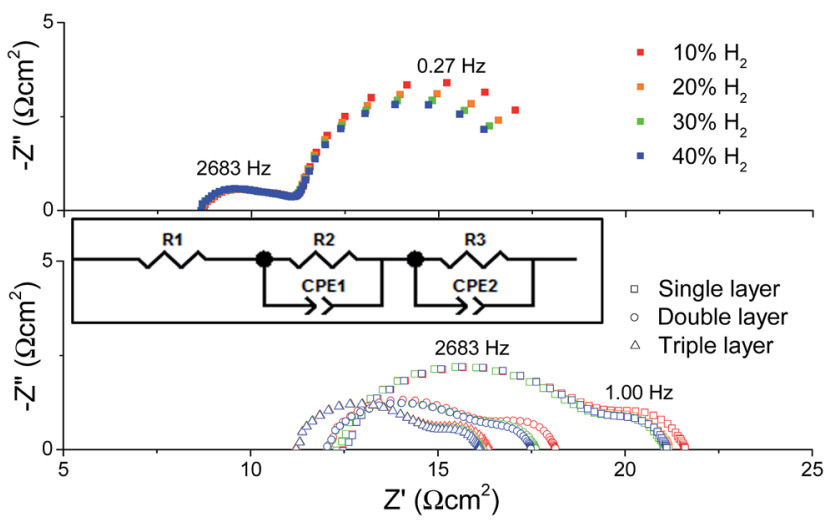

Fig. 6 Impedance spectra for symmetrical cells tested at $500{ }^{\circ} \mathrm{C}$ produced from scaffolds heat-treated at $1300{ }^{\circ} \mathrm{C}$ (top) and $1000{ }^{\circ} \mathrm{C}$ (bottom). The characteristic frequencies of each response are displayed on the plot for the $10 \% \mathrm{H}_{2}$ single layer samples only. The inset shows the equivalent circuit used for modelling.

from $120 \mathrm{~kJ} \mathrm{~mol}^{-1}$ for one layer, $111 \mathrm{~kJ} \mathrm{~mol}^{-1}$ for two layers and $97.4 \mathrm{~kJ} \mathrm{~mol}^{-1}$ for three. For the sample with a scaffold heattreated at $1300{ }^{\circ} \mathrm{C}$, the calculated activation energy of $128 \mathrm{~kJ}$ $\mathrm{mol}^{-1}$ was comparable to the single layered cell heat-treated at $1000{ }^{\circ} \mathrm{C}$.

Comparing the low frequency response that was assigned as gas diffusion, the samples heat-treated at $1000{ }^{\circ} \mathrm{C}$ showed much smaller polarisation than the sample heat-treated at $1300{ }^{\circ} \mathrm{C}$.

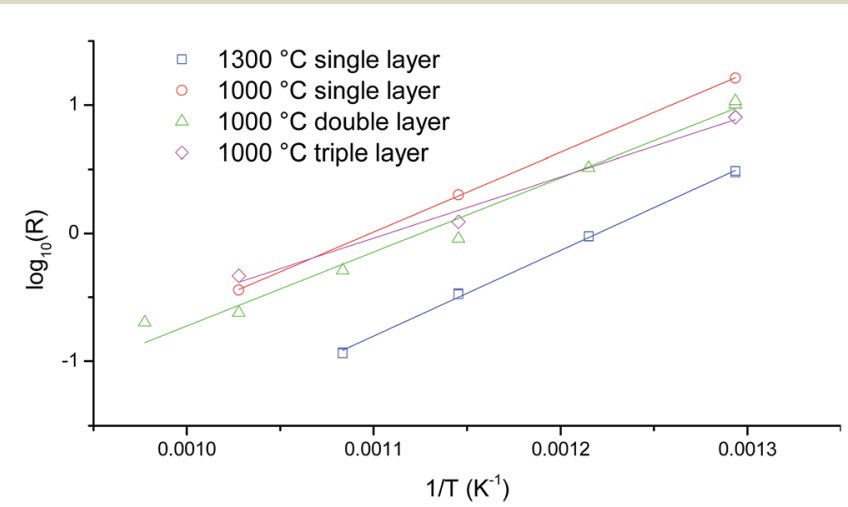

Fig. 7 Arrhenius plots of the log of the resistance of the higher frequency response against the inverse of the temperature.
This was consistent with the higher level of porosity demonstrated by USAXS and SEM. For the samples heat-treated at 1000 ${ }^{\circ} \mathrm{C}$, the resistance decreased with increasing number of layers, indicating that the active electrochemical region was increasing in size. Comparing the overall resistances, it could be seen that the scaffolds heat-treated at $1000{ }^{\circ} \mathrm{C}$ all possessed lower resistances for the electrode component of the resistance than the scaffold heat-treated at $1300{ }^{\circ} \mathrm{C}$, with increasing numbers of layers decreasing the overall resistance. Interestingly, the ohmic component of the resistance (the intercept with the $x$-axis at the high frequency end) was larger by up to $50 \%$ in all three samples heat-treated at $1000{ }^{\circ} \mathrm{C}$ (compared to the sample heat-treated at $1300{ }^{\circ} \mathrm{C}$ ). This suggested that the electrical contacts were poorer, either between the electrolyte and the anode, or between the anode and the current collector. Previous work on infiltrated electrodes using FIB-SEM tomography ${ }^{26}$ has shown that the level of percolation of nickel is sensitive to the loading of nickel, it may be that the higher porosity of the lower temperature samples results in a poorer connectivity of nickel at the loadings used in these samples.

Fuel cells were fabricated from four different scaffolds; single and double layer scaffolds heat-treated at $1000{ }^{\circ} \mathrm{C}$, and the same ones heat-treated at $1300{ }^{\circ} \mathrm{C}$. Despite the slightly better performance noted in the triple-layered symmetrical cells, these were not produced due to the increased complexity of printing the extra layer. The measured power densities in $50 \% \mathrm{H}_{2}$ (Fig. 8) showed that the cells produced using scaffolds heat-treated at $1300{ }^{\circ} \mathrm{C}$ outperformed the cells produced using scaffolds heat-treated at $1000{ }^{\circ} \mathrm{C}$ (when tested at $800{ }^{\circ} \mathrm{C}$ ). However, at lower testing temperatures, the cells made from scaffolds heat-treated at $1000{ }^{\circ} \mathrm{C}$ produced higher power densities. As shown in Fig. 7, the different heat-treatment temperatures produce different activation energies derived from the high frequency response in the impedance spectra. This in turn means that the cells will differ in their response to changing testing temperature. In this case, due to their lower activation energy the activity of the cells heat-treated at $1000{ }^{\circ} \mathrm{C}$ does not decline as rapidly with temperature, with the result that they outperform the cells heat-treated at $1300{ }^{\circ} \mathrm{C}$ at the lower testing temperatures.

Finally, the two double layered cells were also tested in syngas (Fig. 9). For these tests, the cell made using a scaffold 

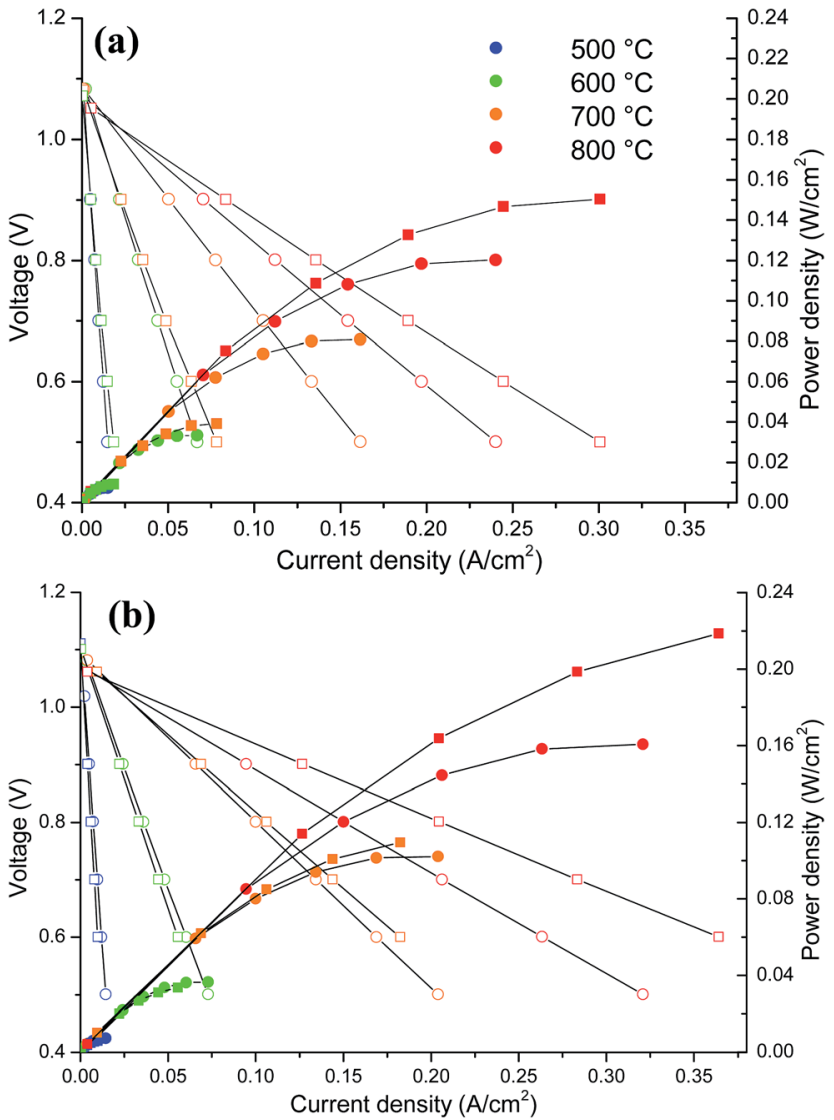

Fig. 8 Power density curves measured under $50 \% \mathrm{H}_{2}$ for (a) single and (b) double layered scaffolds showing the effects of number of layers and scaffold heat-treatment temperature. Scaffolds heat-treated at $1000{ }^{\circ} \mathrm{C}$ are circles while those heat-treated at $1300^{\circ} \mathrm{C}$ are squares. Power densities are closed symbols, while voltages are open symbols. The same legend is used for (a) and (b).

heat-treated at $1000{ }^{\circ} \mathrm{C}$, outperformed the cell made using a scaffold heat-treated at $1300{ }^{\circ} \mathrm{C}$ (under all conditions). The mix of syngas used $\left(15 \% \mathrm{H}_{2}, 25 \% \mathrm{CO}\right)$ contained around $80 \%$ of the energy of the $50 \% \mathrm{H}_{2}$ fuel gas used for the hydrogen fuel cell tests. As expected, the cell produced using a scaffold heattreated at $1300{ }^{\circ} \mathrm{C}$, produced power densities of $c a .80 \%$ of the values produced under hydrogen. However, the cell produced using a scaffold heat-treated at $1000{ }^{\circ} \mathrm{C}$ gave higher power densities than expected, indicating that the electrochemical conversion was more efficient under syngas than under hydrogen. The performance of all the cells was stable over the 40 minute exposure to syngas required for the performance testing at each temperature. Tests under hydrogen before and after the syngas tests at each temperature showed no observable degradation of performance.

\section{Conclusions}

A strategy for incorporating nanoparticles into solid oxide fuel cell anodes has been demonstrated, and has been shown to confer benefits including lower onset of sintering temperatures, higher porosity and ultimately better

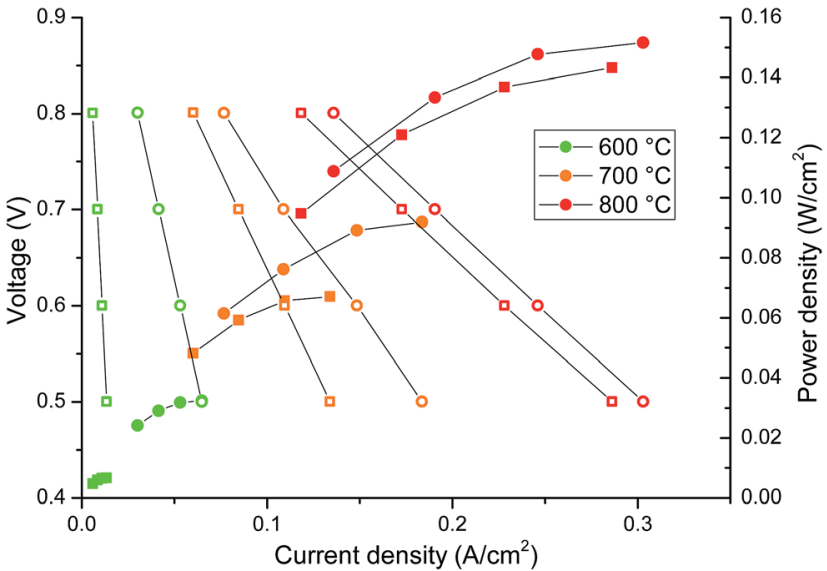

Fig. 9 Fuel cell tests under humidified $15 \% \mathrm{H}_{2}, 25 \% \mathrm{CO}$ syngas showing the effect of scaffold sintering temperature. The scaffold heat-treated at $1000^{\circ} \mathrm{C}$ is in circles while the one heat-treated at 1300 ${ }^{\circ} \mathrm{C}$ is squares. Power densities are filled symbols while voltages are open symbols.

performance at lower temperatures and under syngas. The nanoparticles used along with conventional micron-sized CGO particles appeared to act as a glue to enable the lower sintering temperatures. Low temperature routes towards solid oxide fuel cells should allow the use of more advanced catalysts, finer microstructure and materials which are not stable at higher temperatures.

\section{Acknowledgements}

PB would like to thank the H2FCSUPERGEN program for funding, and the Department of Earth Science \& Engineering and the Energy Futures Lab at Imperial College London for funding for JY under the UROP scheme. ERT would like to thank funding provided by the EPSRC Advancing Biogas Utilization through Fuel Flexible SOFC project [EP/I037016/1]. EPSRC is also thanked for funding the pilot plant and confined jet mixer development and for funding RG and CJT [EP/ E040551/1]. KCC and JI would like to thank the U.S. Department of Energy (DOE), Solid State Energy Conversion Alliance (SECA). ChemMatCARS Sector 15 is principally supported by the National Science Foundation/DOE under grant number NSF/ CHE-0822838. Use of the Advanced Photon Source was supported by the DOE, Office of Science, Office of Basic Energy Sciences, under Contract no. DE-AC02-06CH11357.

\section{Notes and references}

1 D. J. L. Brett, A. Atkinson, N. P. Brandon and S. J. Skinner, Chem. Soc. Rev., 2008, 37(8), 1568-1578.

2 A. J. Jacobson, Chem. Mater., 2010, 22(3), 660-674.

3 E. Ruiz-Trejo, P. Boldrin, A. Lubin, F. Tariq, S. Fearn, R. Chater, S. N. Cook, A. Atkinson, R. I. Gruar, C. J. Tighe, J. Darr and N. P. Brandon, Chem. Mater., 2014, 26(13), 3887-3895. 
4 J. Sunarso, S. Baumann, J. M. Serra, W. A. Meulenberg, S. Liu, Y. S. Lin and J. C. D. da Costa, J. Membr. Sci., 2008, 320(1-2), 13-41.

5 A. Thursfield, A. Murugan, R. Franca and I. S. Metcalfe, Energy Environ. Sci., 2012, 5(6), 7421-7459.

6 G. Q. Lu, J. C. D. da Costa, M. Duke, S. Giessler, R. Socolow, R. H. Williams and T. Kreutz, J. Colloid Interface Sci., 2007, 314(2), 589-603.

7 M. Navarro, A. Michiardi, O. Castano and J. A. Planell, J. $R$. Soc., Interface, 2008, 5(27), 1137-1158.

8 A. Ikesue and Y. L. Aung, Nat. Photonics, 2008, 2(12), 721-727.

9 J.-Y. Kim and N. A. Kotov, Chem. Mater., 2013, 26(1), 134-152.

10 M. R. Somalu and N. P. Brandon, J. Am. Ceram. Soc., 2012, 95(4), 1220-1228.

11 M. R. Somalu, V. Yufit and N. P. Brandon, Int. J. Hydrogen Energy, 2013, 38(22), 9500-9510.

12 M. R. Somalu, A. Muchtar, M. G. Baboli, V. Yufit, I. P. Shapiro, P. Xiao and N. P. Brandon, ECS Transactions, 2013, 57(1), 1321-1330.

13 M. R. Somalu, V. Yufit, I. P. Shapiro, P. Xiao and N. P. Brandon, Int. J. Hydrogen Energy, 2013, 38(16), 67896801.

14 P. I. Cowin, C. T. G. Petit, R. Lan, J. T. S. Irvine and S. W. Tao, Adv. Energy Mater., 2011, 1(3), 314-332.

15 K. Jono, S. Suda and M. Hattori, Effect of Graded Porous Structure on Ni-YSZ Anode Performance, in Solid Oxide Fuel Cells 10, ed. K. Eguchi, S. C. Singhai, H. Yokokawa and H. Mizusaki, 2007, vol. 7, pp. 1541-1546.
16 M. J. Lee, J. H. Jung, K. Zhao, B. H. Kim, Q. Xu, B. G. Ahn, S. S. H. Kim and S. Y. Kim, J. Eur. Ceram. Soc., 2014, 34(7), 1771-1776.

17 C. J. Tighe, R. Q. Cabrera, R. I. Gruar and J. A. Darr, Ind. Eng. Chem. Res., 2013, 52(16), 5522-5528.

18 A. Cabanas, J. A. Darr, E. Lester and M. Poliakoff, Chem. Commun., 2000, (11), 901-902.

19 A. Cabanas, J. A. Darr, E. Lester and M. Poliakoff, J. Mater. Chem., 2001, 11(2), 561-568.

20 X. Weng, J. K. Cockcroft, G. Hyett, M. Vickers, P. Boldrin, C. C. Tang, S. P. Thompson, J. E. Parker, J. C. Knowles, I. Rehman, I. Parkin, J. R. G. Evans and J. A. Darr, J. Comb. Chem., 2009, 11(5), 829-834.

21 P. Boldrin, A. K. Hebb, A. A. Chaudhry, L. Otley, B. Thiebaut, P. Bishop and J. A. Darr, Ind. Eng. Chem. Res., 2007, 46(14), 4830-4838.

22 X. Weng, P. Boldrin, I. Abrahams, S. J. Skinner, S. Kellici and J. A. Darr, J. Solid State Chem., 2008, 181(5), 1123-1132.

23 A. A. Chaudhry, S. Haque, S. Kellici, P. Boldrin, I. Rehman, F. A. Khalid and J. A. Darr, Chem. Commun., 2006, (21), 2286-2288.

24 R. I. Gruar, C. J. Tighe and J. A. Darr, Ind. Eng. Chem. Res., 2013, 52(15), 5270-5281.

25 P. Fuoss, K. C. Chang and H. You, J. Electron Spectrosc. Relat. Phenom., 2013, 190, 75-83.

26 M. Kishimoto, M. Lomberg, E. Ruiz-Trejo and N. P. Brandon, J. Power Sources, 2014, 266, 291-295. 